\title{
The differential role of HTRA 1 in HPV-positive and HPV-negative cervical cell line proliferation
}

\author{
Bruna Stuqui ${ }^{1}$, André Luis Giacometti Conceição ${ }^{1}$, Lara Termini ${ }^{2}$, Laura Sichero ${ }^{2}$, Luisa Lina Villa ${ }^{2,3}$, Paula Rahal ${ }^{1}$ \\ and Marília de Freitas Calmon ${ }^{1 *}$
}

\begin{abstract}
Background: High-risk human papillomaviruses (HPVs) are strongly associated with the development of some malignancies. The E6 and E7 viral oncoproteins are the primary proteins responsible for cell homeostasis alteration and immortalization. Furthermore, the E6 protein from high-risk HPVs can interact with the PDZ (PSD-90/Dlg/ZO-1) domains of cellular proteins, triggering cell transformation. One protein that is associated with pathological conditions and has a PDZ domain is the protease HTRA1 (high temperature requirement 1). This protein is poorly expressed in some cancers, suggesting a tumor suppressor role. The aim of this study was to evaluate the effect of HTRA1 overexpression in HPV16-positive (CasKi) and HPV-negative (C33) cervical cell lines.
\end{abstract}

Methods: The cells were transfected with a vector containing the HTRA1 ORF or an empty vector. HTRA1 overexpression was confirmed by qRT-PCR. The cells were subjected to cell proliferation, colony formation, apoptosis and cell cycle assays.

Results: C33 cells expressing HTRA1 grew significantly fewer colonies and showed less proliferation than cells without HTRA1 expression. In contrast, in the CasKi cells overexpressing HTRA1, there was an increase in the cell growth rate and in the colonies density compared to cells expressing low levels of HTRA1. An apoptosis assay showed that HTRA1 does not interfere with the apoptosis rate in these cells. A cell cycle immunofluorescence assay revealed more CasKi cells overexpressing HTRA1 in the S phase and more C33 HTRA1-transfected cells in the G0/G1 phase, suggesting that HTRA1 plays different roles in the cell cycle progression of these cells.

Conclusions: HTRA1 overexpression prevents cell proliferation in the HPV-negative cell line and increases cell proliferation in the HPV-positive cell line. Although the E6/HTRA1 interaction has already been described in the literature, more studies are required to confirm whether the present functional findings are a result of this interaction.

Keywords: HTRA1, Cell proliferation, HPV, PDZ

\section{Background}

High-risk human papillomaviruses (HPVs) are DNA viruses strongly implicated in the development of some malignances, such as cancer of the cervix (99\%) [1], anal canal (80-85\%) [2], vulva (40\%) [3], vagina ( 70 \%) [3], penis $(\sim 50 \%)$ [4] and oropharynx (25\%) [5]. There are

\footnotetext{
* Correspondence: macal131@gmail.com

${ }^{1}$ Department of Biology, Instituto de Biociências, Letras e Ciências Exatas -

IBILCE/UNESP, Rua Cristóvão Colombo n²265, Jardim Nazareth, CEP

15054-000 São José do Rio Preto, SP, Brazil

Full list of author information is available at the end of the article
}

over 200 types of HPVs identified [6], but the malignant transformation of cervical epithelial cells is associated with persistent high-risk HPV infections, such as HPV 16 and 18 [7]. HPV 16 is responsible for up to $50 \%$ of cervical cancers worldwide [8].

Cell pathways used by viral oncoproteins during viral replication are frequently disrupted, contributing to the development of HPV-associated cancers [9]. The E7 oncoprotein binds to the retinoblastome protein $(\mathrm{pRb})$ and targets it for degradation, resulting in the release and activation of transcription factors (E2F) that drive $\mathrm{S}$ 
phase progression [10]. In the same way, the E6 oncoprotein binds to a cellular protein, E6-AP, and this complex interacts with $\mathrm{p} 53$, resulting in the ubiquitin-dependent degradation of the tumor suppressor p53 [11]. E6 is also responsible for regulating the transcription of some genes, for example, suppressing the expression of some tumor suppressors [12-14]. The E6 carboxy-terminal region conserved in high-risk HPVs is able to recognize and bind to human proteins containing PDZ (PSD-90/Dlg/ZO-1) domains, triggering their degradation, which increases E6 stability in infected cells $[15,16]$. These cellular proteins are localized at the interfaces of cell-cell contacts and form signaling complexes that modulate cell growth, cell polarity, and cell adhesion [16-19]. The E6/cellular protein interactions are important to cancer progression induced by the virus [20].

The HTRA1 (high temperature requirement 1) protein is associated with several pathological conditions. This protease has a PDZ domain and is encoded by a gene located on chromosome 10 (10q26). Human HTRA1 belongs to a family of serine proteases involved in several important biological functions, such as protein quality control, cell growth, differentiation, apoptosis and degradation of extracellular matrix proteins $[21,22]$. The HTRA1 protein contains an $\mathrm{N}$-terminal regulatory domain, an insulin-like growth factor binding protease (IGFBP) domain, a trypsin-like serine protease domain and a $\mathrm{C}$ terminal PDZ domain [23, 24]. The specific role of the PDZ domain of HTRA1 is not clear; however, it is known that PDZ recognizes C-terminal and internal hydrophobic sequences of target proteins, regulating HTRA1 protease activity $[25,26]$.

HTRA1 is involved in several pathologies [27-29] and some types of cancer [30-36]. This protease is expressed in several tissues, and transcription of its gene is highly regulated in both developing and adult tissues [24]. HTRA1 expression is decreased in some cancers, such as melanomas and lung and ovarian cancer, and the reduction of cell proliferation after an increase of its expression suggests a tumor suppressor role for this protein [31, 32, 36]. HTRA1 transcript downregulation was also observed in human keratinocytes immortalized with HPV16 compared to normal keratinocytes [37].

Although HTRA1 has been shown to interact with the E6 oncoprotein of high-risk HPVs, no studies have evaluated the role of HTRA1 in HPV-positive cells. Thus, in the present study, we investigated HTRA1 protein function in HPV-positive and HPV-negative cell lines.

\section{Methods}

\section{Cell lines}

HPV-16 positive (CasKi) (ATCC: CRL-1550) and HPVnegative (C33) (ATCC: HTB-31) human cervical carcinoma cell lines were grown in DMEM medium containing
10 \% FBS (Fetal bovine serum) (Cultilab, SP, Brazil), supplemented with $100 \mathrm{U} / \mathrm{ml}$ penicillin (Invitrogen, Grand Island, NY, USA) and $100 \mu \mathrm{g} / \mathrm{ml}$ streptomycin (Invitrogen, Grand Island, NY, USA) and were grown in a $37{ }^{\circ} \mathrm{C}, 5 \%$ $\mathrm{CO}_{2}$ atmosphere.

\section{Plasmids and transfection}

pCMV6/Entry and pCMV6/HTRA1 were obtained from Origene Technologies (Origene Technologies, Rockville, MD, USA). pCMV6 vectors contain the neomycin phosphotransferase gene, which allows selection with a neomycin analog such as G418 (Sigma-Aldrich, St. Louis, MO, USA). The expression vectors were transfected into cell lines using Fugene HD (Promega, Madison, WI, USA) according to the manufacturer's manual.

\section{Colony formation assay and cell growth curves}

Forty-eight hours after transfection with pCMV6 or pCMV6/HTRA1, CasKi $\left(9 \times 10^{4}\right)$ and C33 $\left(6 \times 10^{4}\right)$ cells were trypsinized and plated in 6-well plates in media containing $800 \mu \mathrm{g} / \mathrm{ml}$ geneticin (G418, Sigma Aldrich, St Louis, MO, USA). The cells continued to grow for 14 days with media changes every 2 days; colonies were stained with $0.01 \%$ crystal violet. Each experiment was performed in triplicate and in two independent assays.

To determine the cell growth rate, CasKi and C33 cells transfected and selected with G418 for 14 days were plated in 24-well plates (CasKi $3 \times 10^{4}$ and C33 $1 \times 10^{5}$ cells). After 24, 48 and $72 \mathrm{~h}$, the cell number was counted in a Neubauer Improved chamber.

\section{Apoptosis assay}

Apoptotic cells were analyzed using a FITC Annexin V Apoptosis Detection Kit II (556570 - BD Biosciences, San Diego, CA, USA) according to the manufacturer's instructions after they were transfected with pCMV6/ HTRA1 or empty vectors and subjected to 14 days of selection with geneticin. The cells were washed with PBS twice and then resuspended in binding buffer, and $5 \mu \mathrm{L}$ FITC-Annexin V and $5 \mu \mathrm{L}$ Propidium Iodide (PI) were added, after which the cells were incubated for $15 \mathrm{~min}$ in the dark at room temperature. The cells were analyzed using an easyCyte 5-HT flow cytometer (Millipore Guava Technologies, Hayward, USA). The data shown are from two independent experiments.

\section{Cell cycle analysis}

After transfection and 14 days of selection with geneticin, the cell cycle was synchronized by the removal of FBS, and the cell cycle phases were assessed using the Cell Cycle Immunofluorescence Kit (558662 - BD Biosciences, San Diego, CA, USA). S phase cells were identified using BrdU and AlexaFluor 488 Mouse anti-BrdU, M phase cells were detected with an AlexaFluor 647 Rat anti-Histone 


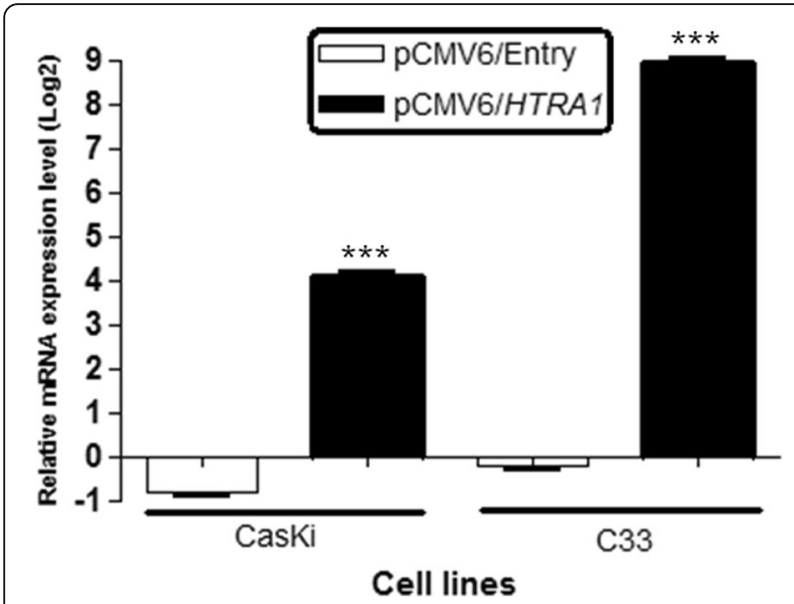

Fig. 1 HTRA1 overexpression in HPV-positive (CasKi) and HPV-negative (C33) cell lines. CasKi and C33 cells were transiently transfected with pCMV6/Entry (empty vector) or pCMV6/HTRA1 and the overexpression of HTRA1 was confirmed $48 \mathrm{~h}$ post-transfection by qRT-PCR. Quantitative mRNA expression of the HTRA1 gene in both cell lines after transfection with pCMV6/HTRA1 or the empty vector is shown as the fold change (log2) relative to expression
H3 antibody (pS28) and G0/G1 phases were measured with DAPI, according to the manufacturer's instructions. The cells were analyzed using an LSM 710 confocal microscope (Zeiss, Germany).

\section{RNA extraction and qRT-PCR}

Total RNA was obtained using TRIzol reagent (Life Technologies, Grand Island, NY) according to the manufacturer's instructions. Approximately $5 \mu \mathrm{g}$ of total RNA from each sample were used to synthesize cDNA using the High Capacity cDNA Kit (Applied Biosystems, Foster City, CA, USA) according to the manufacturer's instructions. Real-Time PCR was performed using an ABI Prism 7300 Real Time PCR system and SYBR Green PCR Core Reagent (Applied Biosystems, Warrington, UK) following the manufacturer's protocol. The primer sequences were designed using Primer 3 software: E6 HPV16 - GACCCA GAAAGTTACCACAG (Forward) and CATAAATCCCG AAAAGCAAAG (Reverse); E7 HPV16 - ACAAGCAGA ACCGGACAGAG (Forward) and TGCCCATTAACAGG TCTTCC (Reverse); HTRA1 - CGCACTCATCAAAATT GACC (Forward) and CTGTGTTTTGAAGGGAAAACG (Reverse); GAPDH (endogenous control): ACCCACTCCT

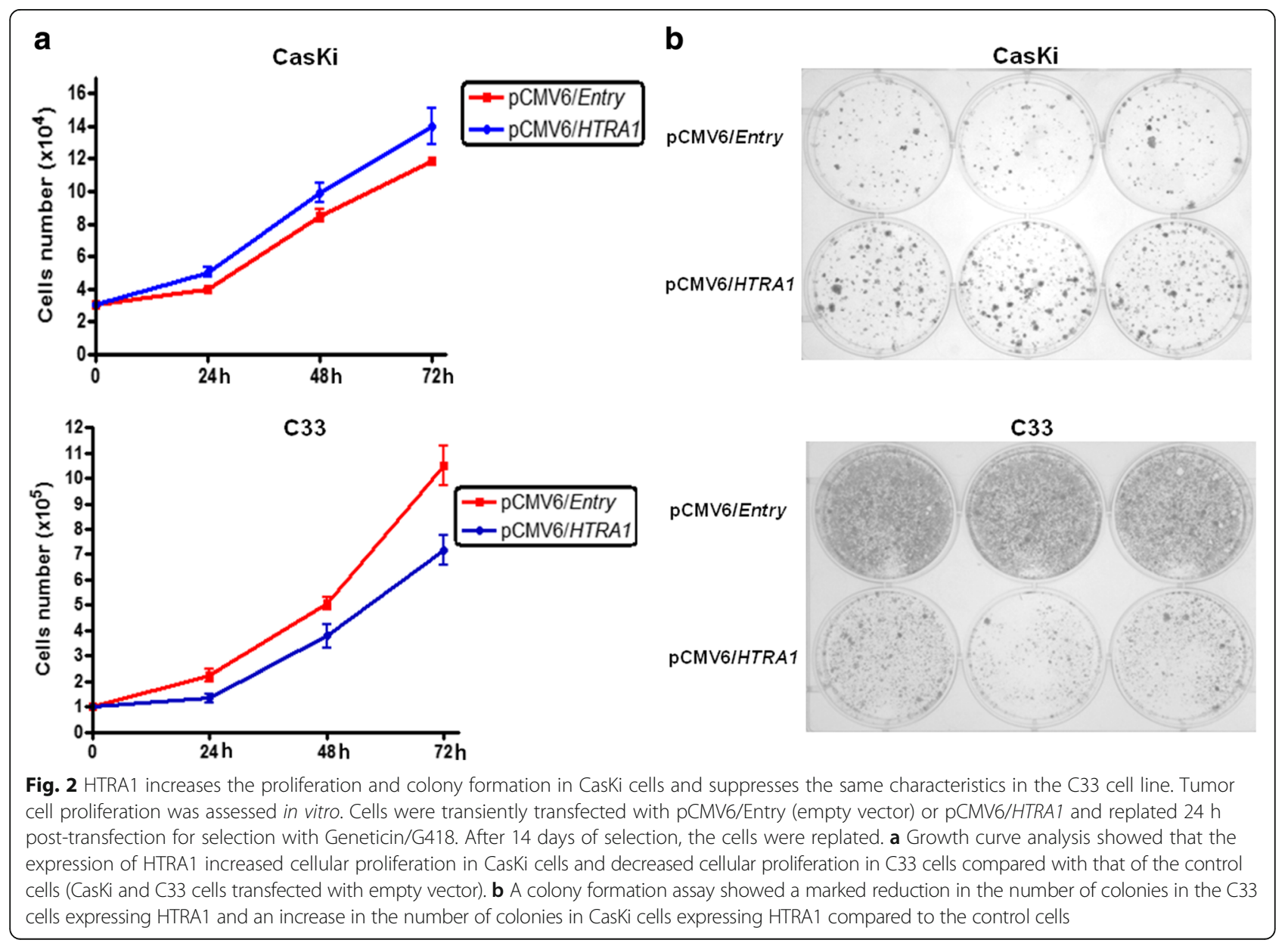


CCACCTTTGA (Forward) and CTGTTGCTGTAGCCA AATTCGT (Reverse). In brief, the reaction mixture (20 $\mu \mathrm{L}$ total volume) contained $25 \mathrm{ng}$ of cDNA, genespecific forward and reverse primers for each gene, and $10 \mu \mathrm{L}$ of 2x Quantitative SYBR Green PCR Master Mix. The samples were tested in triplicate. The relative expression of each specific gene was calculated using the following formula: $R=(E \text { target })^{\Delta \mathrm{Ct}}$ target (control - sample) $/(\mathrm{E}$ endogenous) ${ }^{\Delta \mathrm{Ct} \text { endogenous (control - sample) }}$, which was published previously [38]; a cutoff higher than a 2-fold change was used.

\section{Statistical analysis}

Statistical analysis was performed using GraphPad Prism 5 Software. Functional comparisons between cells overexpressing HTRA1 and cells with low HTRA1 expression were performed using Student's $t$ test. In all analyses, the differences were considered statistically significant whenever $p<0.05$.

\section{Results}

HTRA1 overexpression in HPV-positive and HPV-negative cell lines

After transfection with the pCMV6/HTRA1 expression vector or with an empty vector (pCMV6/Entry), HTRA1 expression in the CasKi and C33 cell lines was accessed using qRT-PCR. The HTRA1 gene was upregulated compared to cells transfected with the empty vector in both cell lines after transfection with the pCMV6/HTRA1 vector $(* * * 00.001)$ (Fig. 1).

\section{HTRA1 plays different roles in cell proliferation and colony formation in CasKi and C 33 cell lines}

Cell proliferation and colony formation ability were assessed after 14 days of selection of the transfected cells with G418. Our results demonstrate that CasKi cells expressing HTRA1 had an increased proliferation rate (Fig. 2a) and colonies density compared with the corresponding control cells (Fig. 2b). However, in C33 cells overexpressing HTRA1, a reduction in the cell growth rate (Fig. 2a) and colony number was observed compared to cells transfected with the empty vector (Fig. 2b).

\section{The apoptosis rate is not influenced by HTRA 1}

The ability of HTRA1 to induce apoptosis was also evaluated. The rate of apoptosis was assessed using FITCAnnexin V/PI after transfection with pCMV6/HTRA1 and selection with G418. No significant difference in apoptosis was observed in both cell lines, whether overexpressing or underexpressing HTRA1 $(p>0.05)$ (Fig. 3).

\section{HTRA1 changes cell cycle progression}

Cell cycle analysis on HPV-positive and HPV-negative cells was performed using a cell cycle immunofluorescence assay

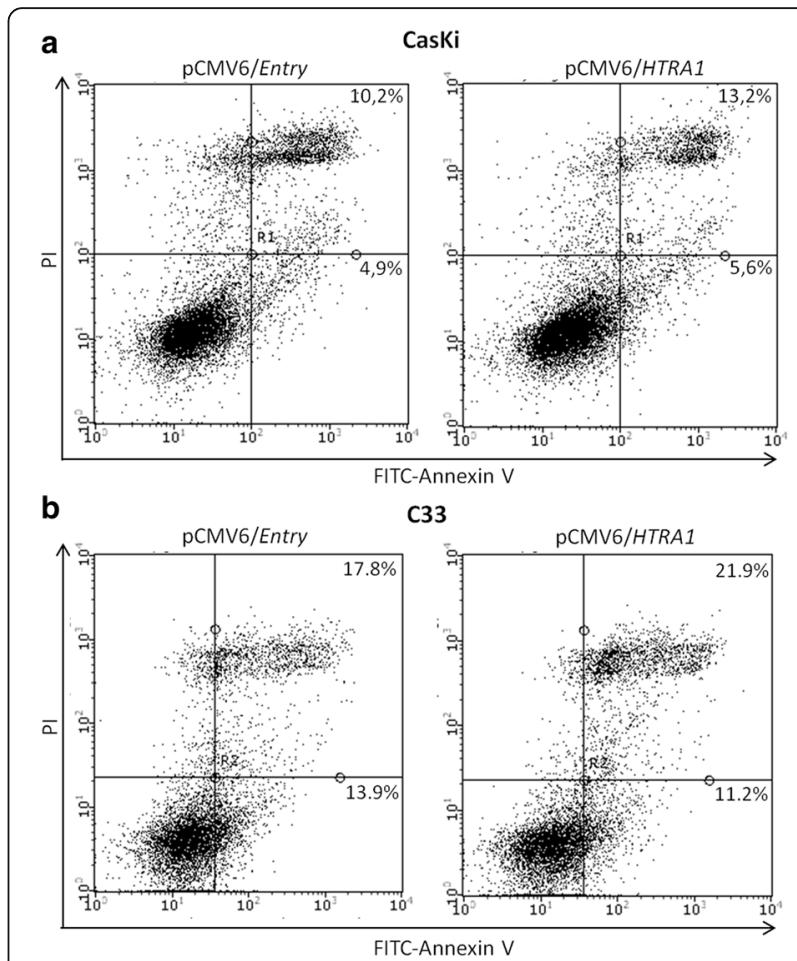

Fig. 3 Effect of HTRA1 on apoptosis. Apoptosis in the CasKi (a) and C33 (b) cell lines was analyzed by flow cytometry after transfection and 14 days of G418 selection. No difference in apoptosis was observed in either cell line between cells overexpressing HTRA1 and those with low HTRA1 expression levels $(p>0.05)$. Viable cells are located in the bottom left (FITC-Annexin $V$ negative/PI negative), early apoptotic cells in the bottom right (FITC-Annexin $V$ positive/PI negative), late apoptotic or necrotic cells in the top right (FITC-Annexin $V$ positive/PI positive) and necrotic cells in the top left quadrants (FITC-Annexin $V$ negative/PI positive)

after transfection with pCMV6/HTRA1 and selection with G418. There were more CasKi cells overexpressing HTRA1 in the $S$ phase $\left({ }^{* * * * *} p<0.001\right)$ and fewer cells overexpressing HTRA1 in the G0/G1 phase after transfection $(* * * *<<$ 0.001) (Fig. 4a, b, c, g). The opposite was observed in the C33 cell line, in which a higher number of cells overexpressing HTRA1 was observed in the G0/G1 phase ${ }^{* * *} p<$ 0.01) than in C33 cells transfected with the empty vector (Fig. 4d, e, f, h).

\section{Discussion}

In this study, we analyzed the effects of HTRA1 overexpression in HPV-positive (CasKi) and HPV-negative (C33) cell lines. Cervical carcinoma cells (C33) overexpressing HTRA1 had fewer colonies and a lower growth rate than the control. Studies using MTT assays have also reported that HTRA1 overexpression triggers a decrease in cell proliferation [22,33], and colony numbers were reduced in soft agar assays [33]. Different investigations observed the downregulation of HTRA1 expression in various cancers types, such as melanoma, mesothelioma, 

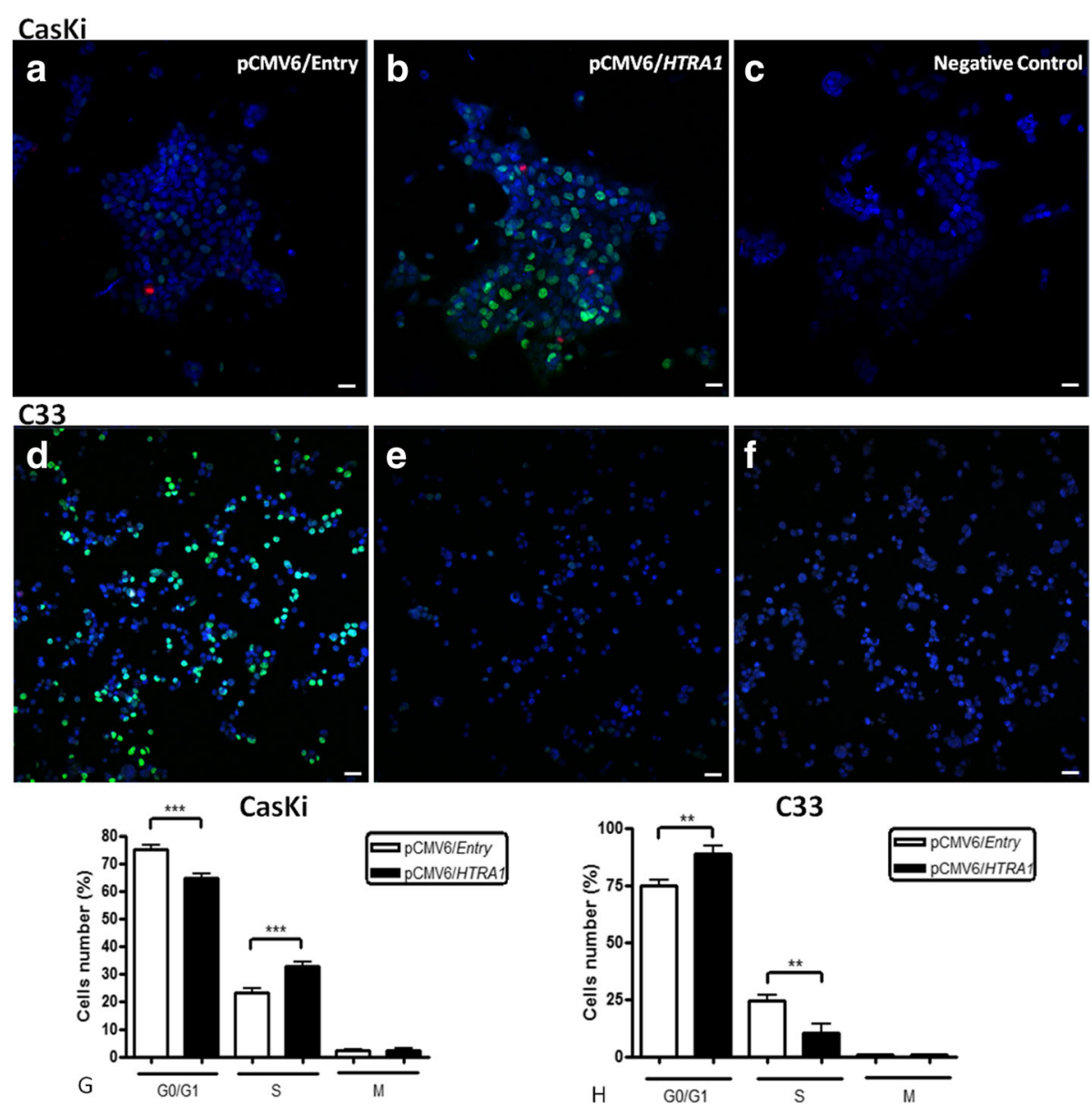

Fig. 4 Effect of HTRA1 on the cell cycle in cell lines. Cell cycle phases in CasKi and C33 cell lines were analyzed post-transfection and after 14 days of G418 selection using an immunofluorescence assay. The number of CasKi cells in the S phase (green, AlexaFluor 488 Mouse anti-BrdU) and mitosis (red, AlexaFluor 647 Rat anti-Histone H3) was increased, while the number of cells in G0/G1 phase (blue) significantly decreased for cells overexpressing HTRA1 (b, g) compared with cells with low HTRA1 expression levels $(\mathbf{a}, \mathbf{g})$. The number of C33 cells overexpressing HTRA1 in G1/G0 was significantly increased (blue, Hoechst) and the number of cells in S phase was decreased (green) (e, $\mathbf{h})$ compared to C33 cells without HTRA1 expression (d, h). $\mathbf{c}$ CasKi and $\mathbf{f}$ C33 cells incubated only with Hoechst were used as negative controls

lung, ovarian, bladder urothelial, breast, gallbladder and gastric cancer [31, 32, 36, 39-43]. Exogenous HTRA1 expression induces apoptosis and a reduction of cell proliferation in transformed cells, suggesting a tumor suppressor role for this protein $[36,44]$.

Xia et al. [45] showed a reduction in cell proliferation and invasion in esophageal squamous cell carcinoma overexpressing HTRA1 due to blockage of the nuclear factor- $\mathrm{k} B$ signaling pathway coupled to a decrease in the Ki-67, Bcl-2 (B-cell lymphoma 2), Bcl-xL (B-cell lymphoma-extra large), cyclin D1 and MMP-9 (matrix metalloproteinase 9) proteins. In endometrial cancer cell lines, exogenous HTRA1 expression resulted in a decrease in the invasive and migration potential of these cells. Thereby, the loss of HTRA1 may contribute to the aggressiveness and metastatic phenotype of cancer cells [35].
In contrast to that observed in C33 cells, in the HPV-16-positive cervical carcinoma cell line (CasKi) HTRA1-overexpressing cells showed an increase in colony formation and cell proliferation. This report is the first to describe the effect of HTRA1 overexpression in cells containing high-risk HPV. The increase in the colony number and cell growth rate in HPV-positive HTRA1transfected cells could be explained by the viral replicative cycle characteristics. These viruses express early proteins E6, E7 and E5 - that interact with cellular proteins and interfere with normal cell cycle regulation. The E6 oncoprotein of high-risk HPVs is able to interact with the PDZ domain of cellular proteins, preventing apoptosis and stimulating the proliferation of infected cells $[46,47]$. The HTRA1 serine protease contains a PDZ domain in its $\mathrm{C}$-terminal region, and for this reason, it is a strong candidate to interact with the E6 protein of high-risk 
HPVs [25, 26], and the association of both proteins may result in the bypass of growth arrest. In fact, interaction between HTRA1 and HPV E6 proteins was observed by Clawson et al. [48], however there are no functional studies that describe the effects of this association.

Some studies suggest that the interaction between the E6 PBM (PDZ domain-binding motif) and the PDZ domains of cellular proteins increases E6 stability, promoting high levels of E6 and HPV genome maintenance in the cell $[16,17]$. Nicolaides [16] showed that the interaction between E6 and the PDZ domain of two cellular proteins involved in cell polarity, MAGI (Membrane Associated Guanylate kinase Inverted) and hScrib (Scribble Homolog Protein), increases E6 levels in immortalized keratinocytes (NIKS), probably by preventing them from proteasomal degradation. Furthermore, NIKS cells transfected with an HPV 16 genome mutated in the E6 carboxy-terminal region presented low levels of E6, and the viral genome was unable to remain as an epissome, becoming degraded or integrated into the host genome. For HPV 31, the loss of the E6 PBM domain was shown to trigger reduction in the viral copy number in human foreskin keratinocytes (HFK) [17].

We speculate that in CasKi cell line, E6 oncoprotein could interact with HTRA1 PDZ domain, triggering high levels of this viral oncoprotein in the cell and enhancing E6 cellular transformation activity, prompting the proliferation of HPV infected cells, which could explain the increased cell proliferation observed in HPV-positive cells overexpressing HTRA1.

The cell cycle was assessed in this study by immunofluorescence to determine whether the changes in cellular proliferation induced by HTRA1 overexpression could be explained by modifications in the proportion of cells in each cell cycle phase. In the HPV-negative cell line, HTRA1 overexpression triggered cell cycle arrest, increasing the number of cells in G0/G1 phase and reducing the number of cells in synthesis (S) phase. In the HPVpositive cell line, HTRA1 overexpression triggered cell cycle progression by increasing the number of cells in $S$ phase and decreasing the number of cells in G0/G1. These results are in agreement with the observed decrease in the colony and cell numbers in C33 cells and increase in colony and cell numbers in the CasKi cell line after HTRA1 overexpression. The data suggest a tumor suppressor role only in HPV-negative cells (C33 cells) and an opposite effect in HPV-positive cells (CasKi cells).

One limitation of our study is that due to the different genetic background of the transformed C33 and CasKi cell lines, our experiments do not allow us to infer the mechanism by which HTRA1 overexpression reduced proliferation only in the HPV-negative cell line. However, it is possible that the interaction between E6 and
HTRA1 showed by immunoprecipitation [48] depends on the PDZ domain and triggers a high level of E6 oncoprotein in the cell, enhancing its cellular transformation activity. However, other studies are necessary to investigate how HTRA1 increases cell proliferation in the CasKi cell line and in other HPV-positive cell lines and tumors.

\section{Conclusions}

HTRA1 overexpression prevents cell proliferation in the HPV-negative cell line, as described in the literature in other tumor cells, via cell cycle arrest in G0/G1. On the other hand, HTRA1 increases cell proliferation in the HPV-positive cell line, inducing cell cycle progression by increasing the number of cells in $\mathrm{S}$ phase and decreasing the number of cells in G0/G1. However, more studies are required to determine whether this high rate of cellular proliferation is a result of the E6/HTRA1 PDZ interaction.

\section{Abbreviations}

BCl-2: B-cell lymphoma 2; BCl-xL: B-cell lymphoma-extra large; FBS: Fetal bovine serum; G418: Geneticin; HFK: Human foreskin keratinocytes; HPV: High-risk human papillomaviruses; hScrib: Scribble homolog protein: HTRA1: High temperature requirement 1; IGFBP: Insulin-like growth factor binding protease domain; MAGl: Membrane Associated Guanylate kinase Inverted; MMP-9: Matrix metalloproteinase 9; NIKS: Immortalized keratinocytes; PBM: PDZ domain-binding motif; PDZ: PSD-90/Dlg/ZO-1 domain; pRb: Retinoblastome protein

\section{Funding}

This research was supported by State of Sao Paulo Research Foundation (FAPESP) (number 2012/11126-2) and National Council for Scientific and Technological Development (CNPq) (number 478800/2013-4), Brazil. The funders had no role in study design, data collection and analysis, decision to publish, or preparation of the manuscript.

\section{Availability of data and materials}

The datasets supporting the conclusions of this article are included within the article.

\section{Authors' contributions}

MFC and PH designed the research, supervised all experiments and drafted this paper. BS executed HTRA1 transfection, proliferation curve, colony formation, apoptosis, cell cycle, statistical analysis and drafted this paper. ALGC performed qRT-PCR experiments. LT, LS and LLV discussed the results and revised the manuscript. All authors read and approved the final manuscript.

\section{Competing interests}

The authors declare that they have no competing interests.

Consent for publication

Not applicable.

Ethics approval and consent to participate

Not applicable.

\section{Author details}

${ }^{1}$ Department of Biology, Instituto de Biociências, Letras e Ciências Exatas IBILCE/UNESP, Rua Cristóvão Colombo n²265, Jardim Nazareth, CEP 15054-000 São José do Rio Preto, SP, Brazil. ${ }^{2}$ Center for Translational Investigation in Oncology, Instituto do Câncer do Estado de São Paulo, Hospital das Clínicas da Faculdade de Medicina da Universidade de São Paulo, Av. Dr. Arnaldo, 251, $8^{\circ}$ andar, Bairro Cerqueira César CEP 01246-000, São Paulo, Brazil. ${ }^{3}$ Department of Radiology and Oncology, Faculdade de 
Medicina, Universidade de São Paulo, Av. Dr. Arnaldo, 251, $8^{\circ}$ andar, Bairro Cerqueira César CEP 01246-000, São Paulo, Brazil.

\section{Received: 8 June 2016 Accepted: 21 October 2016 Published online: 03 November 2016}

\section{References}

1. Callegari ET, Tabrizi SN, Pyman J, Saville M, Cornall AM, Brotherton JML, Garland SM. How best to interpret mixed human papillomavirus genotypes in high-grade cervical intraepithelial neoplasia lesions. Vaccine. 2014:32(32):4082-8.

2. Glynne-Jones R, Nilsson PJ, Aschele C, Goh V, Peiffert D, Cervantes A, Arnold D. Anal cancer: ESMO-ESSO-ESTRO clinical practice guidelines for diagnosis, treatment and follow-up. Ann Oncol. 2014;25:10-20.

3. De Vuyst $\mathrm{H}$, Clifford GM, Nascimento MC, Madeleine MM, Franceschi S. Prevalence and type distribution of human papillomavirus in carcinoma and intraepithelial neoplasia of the vulva, vagina and anus: a meta-analysis. Int J Cancer. 2009;124(7):1626-36.

4. Backes DM, Kurman RJ, Pimenta JM, Smith JS. Systematic review of human papillomavirus prevalence in invasive penile cancer. Cancer Cause Control. 2009;20(4):449-57.

5. Ljubojevic S, Skerlev M. HPV-associated diseases. Clin Dermatol. 2014:32(2):227-34.

6. Bernard HU, Burk RD, Chen Z, van Doorslaer K, zur Hausen H, de Villiers EM. Classification of papillomaviruses (PVs) based on 189 PV types and proposal of taxonomic amendments. Virology. 2010;401(1):70-9.

7. Missaoui N, Hmissa S, Frappart L, Trabelsi A, Abdelkader AB, Traore C, Mokni M, Yaacoubi MT, Korbi S. p16(INK4A) overexpression and HPV infection in uterine cervix adenocarcinoma. Virchows Arch. 2006:448(5):597-603.

8. Freitas LB, Chen ZG, Muqui EF, Boldrini NAT, Miranda AE, Spano LC, Burk RD. Human papillomavirus 16 Non-European variants are preferentially associated with high-grade cervical lesions. Plos One. 2014:9(7):e100746.

9. Hanahan D, Weinberg RA. The hallmarks of cancer. Cell. 2000;100(1):57-70

10. Dyson N, Howley PM, Munger K, Harlow E. The human papilloma virus-16 E7-oncoprotein is able to bind to the retinoblastoma gene-product. Science. 1989;243(4893):934-7.

11. Scheffner M, Huibregtse JM, Vierstra RD, Howley PM. The HPV-16 E6 and E6-AP complex functions as a ubiquitin-protein ligase in the ubiquitination of p53. Cell. 1993;75(3):495-505

12. Cullmann C, Hoppe-Seyler K, Dymalla S, Lohrey C, Scheffner M, Durst M Hoppe-Seyler F. Oncogenic human papillomaviruses block expression of the B-cell translocation gene-2 tumor suppressor gene. Int J Cancer. 2009:125(9):2014-20.

13. Parroche $P$, Touka M, Mansour M, Bouvard V, Thepot A, Accardi R, Carreira C, Roblot GG, Sylla BS, Hasan U, Tommasino M. Human papillomavirus type 16 E6 inhibits p21(WAF1) transcription independently of p53 by inactivating p150(Sal2). Virology. 2011:417(2):443-8.

14. Reiser J, Hurst J, Voges M, Krauss P, Munch P, Iftner T, Stubenrauch F. High-risk human papillomaviruses repress constitutive kappa interferon transcription via E6 to prevent pathogen recognition receptor and antiviral-gene expression. J Virol. 2011:85(21):11372-80.

15. Lee SS, Weiss RS, Javier RT. Binding of human virus oncoproteins to hDlg/SAP97, a mammalian homolog of the Drosophila discs large tumor suppressor protein. Proc Natl Acad Sci U S A. 1997:94(13):6670-5.

16. Nicolaides L, Davy C, Raj K, Kranjec C, Banks L, Doorbar J. Stabilization of HPV16 E6 protein by PDZ proteins, and potential implications for genome maintenance. Virology. 2011;414(2):137-45

17. Lee C, Laimins LA. Role of the PDZ domain-binding motif of the oncoprotein E6 in the pathogenesis of human papillomavirus type 31. J Virol. 2004:78(22):12366-77.

18. Fanning AS, Anderson JM. PDZ domains: fundamental building blocks in the organization of protein complexes at the plasma membrane. J Clin Invest. 1999;103(6):767-72.

19. Glaunsinger BA, Lee SS, Thomas M, Banks $L$, Javier R. Interactions of the PDZ-protein MAGI-1 with adenovirus E4-ORF1 and high-risk papillomavirus E6 oncoproteins. Oncogene. 2000;19(46):5270-80.

20. Nagasaka K, Kawana K, Osuga Y, Fujii T. PDZ domains and viral infection: versatile potentials of HPV-PDZ interactions in relation to malignancy. Biomed Res Int. 2013;2013:369712.

21. Clausen T, Southan C, Ehrmann M. The HtrA family of proteases: implications for protein composition and cell fate. Mol Cell. 2002;10(3):443-55.
22. Chien J, Aletti G, Baldi A, Catalano V, Muretto P, Keeney GL, Kalli KR, Staub J, Ehrmann M, Cliby WA, Lee YK, Bible KC, Hartmann LC, Kaufmann SH, Shridhar V. Serine protease HtrA1 modulates chemotherapy-induced cytotoxicity. J Clin Invest. 2006;116(7):1994-2004.

23. Truebestein L, Tennstaedt A, Monig T, Krojer T, Canellas F, Kaiser M, Clausen T, Ehrmann M. Substrate-induced remodeling of the active site regulates human HTRA1 activity. Nat Struct Mol Biol. 2011;18(3):386-8.

24. Zumbrunn J, Trueb B. Primary structure of a putative serine protease specific for IGF-binding proteins. FEBS Lett. 1996;398(2-3):187-92.

25. Karring H, Runager K, Thogersen IB, Klintworth GK, Hojrup P, Enghild JJ. Composition and proteolytic processing of corneal deposits associated with mutations in the TGFBI gene. Exp Eye Res. 2012;96(1):163-70.

26. Murwantoko, Yano M, Ueta Y, Murasaki A, Kanda H, Oka C, Kawaichi M. Binding of proteins to the PDZ domain regulates proteolytic activity of HtrA1 serine protease. Biochem J. 2004:381(Pt 3):895-904.

27. Grau S, Richards PJ, Kerr B, Hughes C, Caterson B, Williams AS, Junker U, Jones SA, Clausen T, Ehrmann M. The role of human HtrA1 in arthritic disease. J Biol Chem. 2006;281(10):6124-9.

28. Coleman HR, Chan CC, Ferris 3rd FL, Chew EY. Age-related macular degeneration. Lancet. 2008;372(9652):1835-45.

29. Vierkotten S, Muether PS, Fauser S. Overexpression of HTRA1 leads to ultrastructural changes in the elastic layer of Bruch's membrane via cleavage of extracellular matrix components. Plos One. 2011;6(8):e22959.

30. Zurawa-Janicka D, Skorko-Glonek J, Lipinska B. HtrA proteins as targets in therapy of cancer and other diseases. Expert Opin Ther Targets. 2010;14(7):665-79.

31. Esposito V, Campioni M, De Luca A, Spugnini EP, Baldi F, Cassandro R, Mancini A, Vincenzi B, Groeger A, Caputi M, Baldi A. Analysis of HtrA1 serine protease expression in human lung cancer. Anticancer Res. 2006;26(5A):3455-9.

32. Chien J, Campioni M, Shridhar V, Baldi A. HtrA serine proteases as potential therapeutic targets in cancer. Curr Cancer Drug Targets. 2009;9(4):451-68.

33. He X, Ota T, Liu P, Su C, Chien J, Shridhar V. Downregulation of HtrA1 promotes resistance to anoikis and peritoneal dissemination of ovarian cancer cells. Cancer Res. 2010;70(8):3109-18.

34. He X, Khurana A, Maguire JL, Chien J, Shridhar V. HtrA1 sensitizes ovarian cancer cells to cisplatin-induced cytotoxicity by targeting XIAP for degradation. Int J Cancer. 2012;130(5):1029-35.

35. Mullany SA, Moslemi-Kebria M, Rattan R, Khurana A, Clayton A, Ota T, Mariani A, Podratz KC, Chien J, Shridhar V. Expression and functional significance of HtrA1 loss in endometrial cancer. Clin Cancer Res. 2011:17(3):427-36.

36. Baldi A, De Luca A, Morini M, Battista T, Felsani A, Baldi F, Catricala C, Amantea A, Noonan DM, Albini A, Natali PG, Lombardi D, Paggi MG. The HtrA1 serine protease is down-regulated during human melanoma progression and represses growth of metastatic melanoma cells. Oncogene. 2002;21(43):6684-8.

37. Termini L, Boccardo E, Esteves GH, Hirata Jr R, Martins WK, Colo AE, Neves EJ, Villa LL, Reis LF. Characterization of global transcription profile of normal and HPV-immortalized keratinocytes and their response to TNF treatment. BMC Med Genomics. 2008:1:29.

38. Pfaffl MW. A new mathematical model for relative quantification in real-time RT-PCR. Nucleic Acids Res. 2001:29(9):e45.

39. Baldi A, Mottolese M, Vincenzi B, Campioni M, Mellone P, Di Marino M, di Crescenzo VG, Visca P, Menegozzo S, Spugnini EP, Citro G, Ceribelli A, Mirri A, Chien J, Shridhar V, Ehrmann M, Santini M, Facciolo F. The serine protease HtrA1 is a novel prognostic factor for human mesothelioma. Pharmacogenomics. 2008;9(8):1069-77.

40. Sahasrabuddhe NA, Barbhuiya MA, Bhunia S, Subbannayya T, Gowda H, Advani J, Shrivastav BR, Navani S, Leal P, Roa JC, Chaerkady R, Gupta S, Chatterjee A, Pandey A, Tiwari PK. Identification of prosaposin and transgelin as potential biomarkers for gallbladder cancer using quantitative proteomics. Biochem Biophys Res Commun. 2014;446(4):863-9.

41. Wu HX, Tong SL, Wu C, Wang WX. HTRA1 gene expression in gastric epithelial cells. Asian Pac J Trop Med. 2014;7(10):765-71.

42. Lorenzi T, Lorenzi M, Altobelli E, Marzioni D, Mensa E, Quaranta A Paolinelli F, Morroni M, Mazzucchelli R, De Luca A, Procopio AD, Baldi A, Muzzonigro G, Montironi R, Castellucci M. HtrA1 in human urothelial bladder cancer: a secreted protein and a potential novel biomarker. Int Cancer. 2013:133(11):2650-61.

43. Lehner A, Magdolen V, Schuster T, Kotzsch M, Kiechle M, Meindl A, Sweep FC, Span PN, Gross E. Downregulation of serine protease HTRA1 is associated with poor survival in breast cancer. Plos One. 2013;8(4):e60359. 
44. Chien J, Staub J, Hu SI, Erickson-Johnson MR, Couch FJ, Smith DI, Crowl RM, Kaufmann SH, Shridhar V. A candidate tumor suppressor HtrA1 is downregulated in ovarian cancer. Oncogene. 2004;23(8):1636-44.

45. Xia J, Wang F, Wang L, Fan Q. Elevated serine protease HtrA1 inhibits cell proliferation, reduces invasion, and induces apoptosis in esophageal squamous cell carcinoma by blocking the nuclear factor-kappaB signaling pathway. Tumour Biol. 2013;34(1):317-28.

46. Doorbar J, Quint W, Banks L, Bravo IG, Stoler M, Broker TR, Stanley MA. The biology and life-cycle of human papillomaviruses. Vaccine. 2012;30 Suppl 5:F55-70.

47. Zekan J, Skerlev M, Milic L, Karelovic D. Human papillomavirus-related diseases of the female lower genital tract: oncogenic aspects and molecular interaction. Coll Antropol. 2014;38(2):779-86.

48. Clawson GA, Bui V, Xin P, Wang N, Pan W. Intracellular localization of the tumor suppressor HtrA1/Prss11 and its association with HPV16 E6 and E7 proteins. J Cell Biochem. 2008;105(1):81-8.

Submit your next manuscript to BioMed Central and we will help you at every step:

- We accept pre-submission inquiries

- Our selector tool helps you to find the most relevant journal

- We provide round the clock customer support

- Convenient online submission

- Thorough peer review

- Inclusion in PubMed and all major indexing services

- Maximum visibility for your research

Submit your manuscript at www.biomedcentral.com/submit
Biomed Central 